\title{
CECILIA AXELL \\ BARNLITTERATURENS \\ TEKNIKLANDSKAP \\ En didaktisk vandring från Nils Holgersson till Pettson och Findus
}

Norrköping: Institutionen för samhälls- och välfärdsstudier, Linköpings universitet, 2015. Skrifter utgivna av Svenska barnboksinstitutet, $\mathrm{nr} 128$ (385 s.)

Cecilia Axells doktorsavhandling Barnlitteraturens tekniklandskap. En didaktisk vandring från Nils Holgersson till Pettson och Findus är omfångsrik både till sidantal och innehåll. Ämnet kan tyckas smalt, att utifrån ett teknikdidaktiskt perspektiv undersöka hur teknik framställs inom barnlitteraturen. Men det blir så pass vitt och brett att ett urval är nödvändigt, då författaren med teknik avser allt från den exploatering av Sveriges naturresurser som beskrivs i Selma Lagerlöfs verk till Sven Nordqvists gestaltning av småskaliga tekniska lösningar på gården. Detta görs i enlighet med den definition av vad teknikdidaktik avser, som inledningsvis görs i studien: att det både handlar om kunskapen om teknikens påverkan på samhället, liksom om hur tekniken fungerar, och hur detta tar sig uttryck i olika former. I studien nämns återkommande att de skönlitterära texterna kan bidra till att skapa förståelse för teknikens betydelse hos verkens primära målgrupp: barn och ungdomar.

På så sätt är syftet med studien välmotiverat. Från många håll höjs röster för att läsning, skönlitteratur och textförståelse inte bara kan vara en angelägenhet för svenskämnet inom grundskolan, utan något som alla typer av lärare bör arbeta med. Man hade kunnat önska att begreppet didaktik också fått syfta på lärarens didaktiska bruk av texterna och inte bara det lärande om teknik som ryms inom berättelsens framställning. Då skulle Axells avhandling kunna göra ännu större nytta inom skolvärlden. Då det gäller dess roll inom forskningen kan man konstatera att det är glädjande att forskning om barnlitteratur inte bara bedrivs inom de litteraturvetenskapliga institutionerna, utan också ses som ett viktigt material på andra håll, i det här fallet inom den nationella forskarskolan i naturvetenska- 
pernas och teknikens didaktik (FontD), vari bland annat Linköpings universitet deltar. Detta kan ses i den inledande bakgrunden, som redogör för olika synsätt på teknik och natursyn snarare än för de referenser som brukar ses inom den barnlitterära forskningstraditionen. Begreppen antropocentrisk och biocentrisk natursyn är bärande och väl fungerande, även om jag saknar ett tydligare avstamp i den ekokritiska litteraturforskningen, som i hög grad handlar om vilka synsätt på tekniska framsteg, ekologi och biologi som litteraturen förmedlar. Men det måste understrykas att dessa delar är rika, omfattande och intressanta att läsa.

Samtidigt är det avhandlingens problem, att den är vid och ofta tappar sitt fokus. Inte på så vis att man som läsare blir uttråkad - författaren verkar drivas av den sympatiska viljan att dela med sig av sin kunskap om stort som smått och det är trevligt att ta del av små biografiska skisser över författarna, för att ta ett exempel. Men att stationen Avesta-Krylbo öppnade 1873, och hur den fungerar för resenärer idag, det är inte relevant information i relation till Karl-Aage Schwartzkopfs böcker om familjen Tuff-Tuff, hur gärna man än vill. Sådant kan vara svårt att se i den egna texten och många liknande utvikningar väcker frågor om hur handledarskapet och seminariebehandlingar av avhandlingens kapitel fungerat under tiden som doktorand.

De texter som behandlas är alla svenska och utkomna under 1900-talet. Urvalet är gjort med hänsyn taget till ett biblioteksmaterial som i någon mån visar på verkens genomslag bland sina läsare, och det är intressant eftersom det ger titlar som uppmärksammades under sin tid men som inte läses idag. Utan det tillvägagångssättet hade vi nog inte fått ta del av Schwartzkopfs verk eller av Otto Witts tekniska sagor. Utöver dessa och de redan nämnda Lagerlöfs Nils Holgersson och Nordqvists Tomtemaskinen studeras verk av Elsa Beskow och Sven Wernströms parafras på Nils Holgersson, Den underbara resan. Alla ses vara relevanta för tematiken, och det är lätt att hålla med om det. Ändå hade ett fokus på texter som, istället för att som Lagerlöfs och Wernströms tar ett helhetsgrepp över landets tekniska utveckling och bruk av naturresurser, enbart fokuserat på de tekniska uppfinningarna och teknikens betydelse för vårt vardagsliv, gett ett material som hade varit mera behändigt för att komma fram till övergripande slutsatser om vad tekniken har betytt och betyder i barnlitteraturen. Även när det gäller tematiken gapar alltså avhandlingen över ett för stort fält. Analyserna av de enskilda verken är var för sig intressanta men otydliga tillsammans. Ordet "vandring" i studiens underrubrik antyder detta. Men det kan också 
ses på ett positivt sätt, att man i den förutsättningslösa forskningen ska ha möjlighet att ta stora kliv, även om man är osäker på vart den vandringen leder.

Studiens sista kapitel är det mest relevanta i relation till en samtida skolkontext eftersom det berör verk som i hög grad läses idag. Här blir också tekniken mest påtaglig och en avgörande del av berättelsens dramaturgi. I Nordqvists Tomtemaskinen rör det mesta byggandet av en anordning som för katten Findus framstår som en riktig tomte. Axell konstaterar att hos Nordqvist står tekniken för kreativitet och uppfinningslusta. "Samtidigt som tekniken löser problem behöver den dock inte vara 'nyttig' och den behöver heller inte underlätta" (s. 301). Och det är en intressant iakttagelse som har bärighet för sviten av bilderböcker om Pettson och Findus i stort. Sista kapitlet är det mest intressanta, trots att det också är den del som visar flest svagheter då det kommer till själva analysen, hantverket som barnlitteraturvetaren utför. Främst kommer det i dagen i resonemang som egentligen saknar betydelse, som frågan om när handlingen tidsmässigt utspelar sig:

Det tekniklandskap som böckerna om Pettson och Findus utspelar sig i är tidsmässigt svårdefinierat eftersom berättelserna kan läsas som att de utspelar sig bortom tid och rum. Att böckernas handling kan äga rum i en ickeidentifierbar tid beror på att de handlar om en ensam äldre man och en katt samt innehåller teknik som inte entydigt och bestämt fixerar berättelsen i en viss tid. (267 f.)

Hur en katt och en gubbe i sig gör berättelsen tidsmässigt svårplacerad är svårt att förstå, och inte heller saknas tekniska tidsmarkörer. En vevgrammofon i Pannkakstårtan talar sitt tydliga språk, liksom avsaknaden av alla de jordbruksmaskiner som idag är framträdande i ett jordbrukslandskap. Axell söker svar på märkliga ställen, i en filmatisering och i förlagets presentationssida. Hon gör ingen stor sak av informationen i dessa forum, men det visar på en osäkerhet $i$ vad som är litteraturanalysens material. I det här fallet hade bilderna kunnat ge tydligare svar, men bildanalysen är inte heltäckande och den tar ett trevande avstamp i Ulla Rhedins kategoriseringar av förhållandet mellan bild och text. Otillfredsställande är att verken placeras i två av kategorierna i något slags helgardering som inte leder fram till ett svar på exempelvis frågan om när detta utspelar sig.

Men trots allt, gällande Nordqvists böcker ger analysen en känsla av den läsglädje och fascination som barnet kan känna inför verken, inte minst då det gäller kluriga lösningar och detaljer. På avhand- 
lingens baksida hävdas att "skönlitterära barnböcker skulle därmed kunna fungera som kreativa utgångspunkter för didaktiska samtal om teknikens natur och dess inverkan på människa, samhälle och natur". Detta gäller inte minst det sista kapitlets material och jag ställer mig frågande till varför inte just detta har undersökts, i relation till fler samtida texter och genom ett möte med barn som läser dessa texter. Varför inte samarbeta med den målgrupp som verken primärt vänder sig till, då det gäller att tolka och förstå vilken inverkan texten har på läsaren? Metodologiskt finns många tillvägagångssätt och det hade gjort studien intressantare både för barnlitteraturvetaren och läraren. Men det är en allmän invändning som kan riktas mot mycket av den forskning kring barnlitteratur och barnkultur där barnen lyser med sin frånvaro.

Efter läsningen av Axells avhandling har jag en nyfikenhet med mig som rör två författarskap jag inte vetat mycket om innan, Karl-Aage Schwartzkopfs och Otto Witts. Men ett intresse har även väckts för hur ett så abstrakt begrepp som läsförståelse skulle kunna tydliggöras på ett bättre sätt då läsningen av skönlitteratur inte primärt ska leda till en förståelse för hur en litterär text är uppbyggd och skapad, utan av någonting helt annat: exempelvis teknikens betydelse i vår vardag.

Martin Hellström

Universitetslektor i litteraturvetenskap

Linnéuniversitetet 